\title{
Application of multivariate technique in method development for the direct determination of copper in petroleum condensate using graphite furnace atomic absorption spectrometry
}

\author{
W. N. L. dos Santos, ${ }^{a}$ F. de S. Dias, ${ }^{a}$ M. S. Fernandes, ${ }^{a}$ M. V. Rebouças, ${ }^{b}$ M. G. R. Vale, ${ }^{c}$ \\ B. Welz ${ }^{d}$ and S. L. C. Ferreira*a \\ ${ }^{a}$ Universidade Federal da Bahia, Instituto de Química, Salvador, Bahia 40170-290, \\ Brasil.E-mail: slcf@ufba.br; Fax: 55-71-2355166 \\ ${ }^{b}$ Brasken, Unidade de Insumos Básicos Camaçari, Bahia 42810-000, Brasil \\ ${ }^{c}$ Universidade Federal do Rio Grande do Sul, Instituto de Química Porto Alegre, \\ Rio Grande do Sul 91501-970, Brasil \\ ${ }^{d}$ Universidade Federal de Santa Catarina, Departamento de Química Florianópolis, \\ Santa Catarina 88040-900, Brasil
}

Received 20th September 2004, Accepted 21st December 2004

First published as an Advance Article on the web 11th January 2005

\begin{abstract}
A method has been developed for the direct determination of copper in petroleum condensate using detergentless micro-emulsions (three-component solutions) and graphite furnace atomic absorption spectrometry. The optimization was performed using a three-level full factorial design, resulting in pyrolysis and atomization temperatures of $920{ }^{\circ} \mathrm{C}$ and $2600{ }^{\circ} \mathrm{C}$, respectively. Using the secondary copper line at 327.4 $\mathrm{nm}$, which is less affected by the magnetic field of the Zeeman-effect background correction system, a characteristic mass of $39 \mathrm{pg}$, and detection limit of $0.4 \mu \mathrm{g}{ }^{-1}$ was obtained using $20 \mu \mathrm{l}$ of micro-emulsion, which corresponds to $1.2 \mu \mathrm{g} 1^{-1}$ in petroleum condensate. The precision, expressed as relative standard deviation, was $2.0 \%$ or $2.8 \%$ for copper concentrations of $30 \mu \mathrm{g}^{-1}$ and $5.0 \mu \mathrm{g} 1^{-1}$, respectively. The spike recovery of $105 \%$ for copper added to a petroleum condensate sample proved that this procedure could be applied satisfactorily to a determination in this matrix.
\end{abstract}

Multivariate techniques of experimental design have been increasingly applied for the optimization of analytical methods. ${ }^{1-6}$ Among these, the full three-level factorial design $\left(3^{k}\right)$ has been little used because it requires quite a number of experiments if the factor number is higher than $2 .^{7}$ Nevertheless, several procedures have been established for graphite furnace atomic absorption spectrometry (GF-AAS) using these multivariate techniques. ${ }^{8-13}$

Copper has an extremely strong poisoning effect upon catalysts used in the petroleum industry, particularly on catalysts based on platinum and palladium, reducing their activity and selectivity. ${ }^{14}$ Copper forms permanent and irreversible compounds with the catalyst, deactivating its active sites. ${ }^{14}$

Because of the importance of copper as a catalyst poison, rapid and reliable methods are required for its determination in a variety of petrochemical products, such as condensate. A direct procedure is proposed using detergentless micro-emulsions and determination by GF-AAS. The optimization of the instrumental conditions of the method was performed using a full three-level factorial design $\left(3^{2}\right)$.

\section{Experimental}

\section{Apparatus}

All experiments were carried out using a Varian Model Spectra AA220Z electrothermal atomic absorption spectrometer with Zeeman-effect background correction, equipped with a Model PSD 100 auto sampler. Graphite tubes with an integrated platform that is attached to the tube at only one point were used, providing minimal contact with the tube and more uniform heating. Argon 99.998\% (White Martins, Brazil) was used as the purge gas. The copper hollow cathode lamp
(UltrAA lamp, Varian) was operated with a current of 4.0 $\mathrm{mA}$, and the analytical line at $327.4 \mathrm{~nm}$ was used with a spectral bandwidth of $0.5 \mathrm{~nm}$.

\section{Reagents and solutions}

Copper base oil standard of $1000 \mathrm{mg} \mathrm{kg}^{-1}$ was supplied by Conostan (Conostan Oil Analysis Standards, Ponca City, OK, USA). A copper stock standard solution of $1000 \mu \mathrm{g} \mathrm{l}^{-1}$ was prepared using propan-1-ol (Merck, Darmstadt, Germany) as solvent.

\section{Samples}

The petroleum condensate samples were collected from the raw material storage tank or directly from the ship in a clean borosilicate bottle and stored at $4{ }^{\circ} \mathrm{C}$ prior to the analysis, which was usually performed within $3 \mathrm{~d}$. The cleaning process of sampling apparatus involved nitric acid and water washings and drying in an oven at $100{ }^{\circ} \mathrm{C}$.

\section{Preparation of micro-emulsions}

The detergentless micro-emulsion ${ }^{15}$ was prepared by mixing 3 $\mathrm{ml}$ of petroleum condensate with $5 \mathrm{ml}$ of propan-1-ol and 600 $\mu \mathrm{l}$ of $0.1 \%$ nitric acid solution, and completed to $10 \mathrm{ml}$ with propanol. The mixture was then vigorously shaken in order to mix the components and a one-phase transparent micro-emulsion was obtained. All calibration solutions for the calibration curves and for analyte addition, using inorganic and organic standards, were prepared in the same way as micro-emulsions. 
Table 1 Graphite furnace temperature program

\begin{tabular}{|c|c|c|c|c|}
\hline Cycle & Step & Temperature $/{ }^{\circ} \mathrm{C}$ & Time/s & Flow $/ 1 \mathrm{~min}^{-1}$ \\
\hline \multirow[t]{3}{*}{ Drying } & 1 & 85 & 5.0 & 3.0 \\
\hline & 2 & 95 & 10.0 & 3.0 \\
\hline & 3 & 120 & 10.0 & 3.0 \\
\hline \multirow[t]{3}{*}{ Pyrolysis } & 4 & 920 & 5.0 & 3.0 \\
\hline & 5 & 920 & 12.0 & 3.0 \\
\hline & 6 & 920 & 3.0 & 0.0 \\
\hline \multirow[t]{2}{*}{ Atomization } & 7 & 2600 & 1.0 & 0.0 \\
\hline & 8 & 2600 & 2.0 & 0.0 \\
\hline Cleaning & 9 & 2700 & 2.0 & 3.0 \\
\hline
\end{tabular}

\section{Optimization of instrumental conditions}

The optimization was carried out using a full three-level factorial design, involving the variables pyrolysis temperature and atomization temperature. The experimental conditions of sample volume of $20 \mu \mathrm{l}$, drying time, drying temperature, pyrolysis time, gas flow and clean step were fixed as recommended by the instrument manufacturer, and are listed in Table 1. A full three-level factorial design was performed in order to determine the critical conditions of the method, which was carried out in random order. Duplicates of each point were performed to compute experimental variance. The analytical response was integrated absorbance (peak area). The experimental data were processed using the STATISTICA computer program. $^{16}$

\section{Results and discussion}

\section{Optimization of the experimental conditions}

A response surface methodology using three-level factorial design was performed, involving the following factors: pyrolysis temperature (varied from $800{ }^{\circ} \mathrm{C}$ to $1200{ }^{\circ} \mathrm{C}$ ) and atomization temperature (from $2400{ }^{\circ} \mathrm{C}$ to $2600{ }^{\circ} \mathrm{C}$ ). Table 2 describes the experiments performed considering the coded and real values and the analytical signals for copper determination. The relation between pyrolysis temperature (PyT), atomization temperature (AT) and analytical signal (AS), considering the coded values, is illustrated by the equation:

$$
\begin{gathered}
(\mathrm{AS})=0.1402+0.0172(\mathrm{AT})-0.004338(\mathrm{AT})^{2}-0 . \\
005044(\mathrm{PyT})-0.01056(\mathrm{PyT})^{2}-0.001588(\mathrm{AT})(\mathrm{PyT})
\end{gathered}
$$

The derivation of this equation as (AT) and (PyT) results in the equation system:

$$
\begin{gathered}
\delta(\mathrm{AS}) / \delta(\mathrm{PyT})=-0.005044-0.02112(\mathrm{PyT})-0.001588(\mathrm{AT}) \\
\delta(\mathrm{AS}) / \delta(\mathrm{AT})=0.0172-0.001588(\mathrm{PyT})-0.008676(\mathrm{AT})
\end{gathered}
$$

The resolution of this equation system results in a maximum point, which is -0.3927 for the pyrolysis temperature, and

Table 2 Matrix of the three-level factorial design

\begin{tabular}{llll}
\hline Experiment & $(\mathrm{AT})^{a}$ & $(\mathrm{PyT})^{a}$ & Analytical signal \\
\hline 1 & $2400(-1)$ & $800(-1)$ & $0.1091 / 0.1066$ \\
2 & $2400(-1)$ & $1000(0)$ & $0.1272 / 0.1233$ \\
3 & $2400(-1)$ & $1200(+1)$ & $0.1008 / 0.1024$ \\
4 & $2500(0)$ & $800(-1)$ & $0.1419 / 0.1339$ \\
5 & $2500(0)$ & $1000(0)$ & $0.1340 / 0.1358$ \\
6 & $2500(0)$ & $1200(+1)$ & $0.1287 / 0.1244$ \\
7 & $2600(+1)$ & $800(-1)$ & $0.1510 / 0.1479$ \\
8 & $2600(+1)$ & $1000(0)$ & $0.1511 / 0.1522$ \\
9 & $2600(+1)$ & $1200(+1)$ & $0.1370 / 0.1367$
\end{tabular}

${ }^{a}$ (AT), atomization temperature. (PyT), pyrolysis temperature.

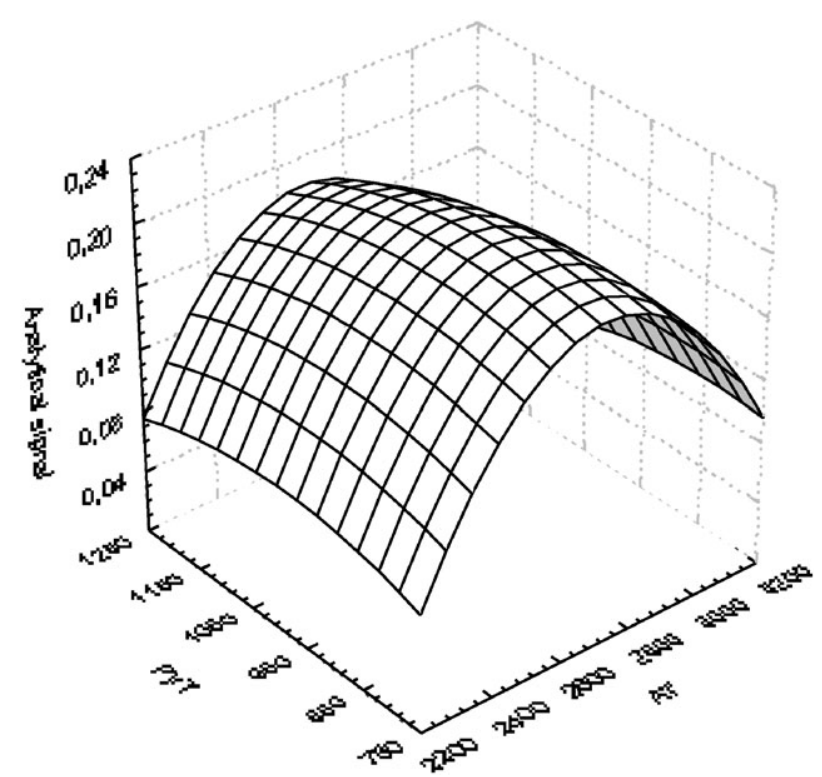

Fig. 1 Response surface for optimization of the pyrolysis and atomization temperatures.

2.054 for the atomization temperature. These results as real values indicate $921{ }^{\circ} \mathrm{C}$ for the pyrolysis temperature and of $2705{ }^{\circ} \mathrm{C}$ for the atomization temperature. At these conditions, the analytical signal predicted is 0.1588 . The correlation coefficient for predicted values using the model equation obtained in the optimization and experimental values is 0.983 . The response surface for the real values is shown in Fig. 1. In it can be seen that the pyrolysis temperature is very robust in the range studied.

The atomization temperature achieved in the optimization step was very high, but it was found suitable to have an atomization temperature of $2600{ }^{\circ} \mathrm{C}$, considering also the results obtained in the three-level factorial design.

\section{Robustness test}

The robustness ${ }^{17,18}$ of the method (defined as the measure of its capacity to reproduce results when the procedure is performed under small changes in the nominal values established) was also evaluated. This test was carried out bearing in mind the experimental conditions: pyrolysis temperature of $920{ }^{\circ} \mathrm{C}$ and atomization temperature of $2600{ }^{\circ} \mathrm{C}$. For this test, was used a two-level full factorial design involving these variables, centered on the experimental conditions described in Table 3. The Analysis of Variance (ANOVA) was used for interpretation of the data from this experiment, and the results demonstrate that this procedure is robust for a variation of $\left( \pm 50{ }^{\circ} \mathrm{C}\right)$ for the variables pyrolysis temperature and atomization temperature.

\section{Analytical figures of merit}

The calibration equations using organic and aqueous standards, and for the analyte addition in petroleum condensate

Table 3 Two-level full factorial design performed in the robustness test

\begin{tabular}{llll}
\hline Experiment & $(\mathrm{AT})^{a}$ & $(\mathrm{PyT})^{a}$ & Analytical signal \\
\hline 1 & 870 & 2550 & 0.1410 \\
2 & 870 & 2650 & 0.1404 \\
3 & 970 & 2550 & 0.1409 \\
4 & 970 & 2650 & 0.1484 \\
5 & 920 & 2600 & $0.1405 / 0.1417 / 0.1425$
\end{tabular}

${ }^{a}$ (AT), atomization temperature. (PyT), pyrolysis temperature. 
Table 4 Calibration equations and correlation coefficients for copper determination in petroleum condensate using micro-emulsions

\begin{tabular}{lll}
\hline Calibration & Equation & $\begin{array}{l}\text { Correlation } \\
\text { coefficient }\end{array}$ \\
\hline $\begin{array}{l}\text { Analyte addition technique } \\
\text { using organic standard }\end{array}$ & $Y=0.00240 X+0.0328$ & 0.9920 \\
$\begin{array}{l}\text { Analytical curve using } \\
\text { organic standard }\end{array}$ & $Y=0.00225 X+0.0033$ & 0.9972 \\
$\begin{array}{l}\text { Analytical curve using } \\
\text { inorganic standard } \\
\begin{array}{l}\text { Analyte addition technique } \\
\text { using inorganic standard }\end{array}\end{array}$ & $Y=0.0043 X+0.0107$ & 0.9994 \\
\hline
\end{tabular}

samples, using optimized conditions, are shown in Table 4 . The slopes of the calibration curve using the organic standard and of the analyte addition curve using the same organic standard are very similar. This means that copper in petroleum condensate can be directly determined using the standard calibration technique with organic standards. The sensitivity obtained for copper in the calibration solution using inorganic standard prepared as a micro-emulsion was about twice as high, which means that these standards could not be used for calibration purposes. The calibration curves for copper using organic standards in propan-1-ol showed a linear response from 1.4 $\mu \mathrm{g}^{-1}$ to $50 \mu \mathrm{g} \mathrm{l}^{-1}$, with a correlation coefficient of 0.9972 . The precision calculated from fifteen consecutive measurements and defined as the coefficient of variation of solutions containing $5.0 \mu \mathrm{g}^{-1}$ and $30 \mu \mathrm{g}^{-1}$ of copper were $2.8 \%$ and $2.0 \%$, respectively. The limit of detection (LOD), defined as the copper concentration that gives a response equivalent to three times the standard deviation $(s)$ of the blank $(n=10)$, was found to be $0.41 \mu \mathrm{g} 1^{-1}$. The characteristics mass was $39 \mathrm{pg}$.

\section{Application-copper determination in petroleum condensate}

Petroleum condensate is a fraction of petroleum comprised of hundreds of hydrocarbon compounds, with a distillation range usually from 30 to $330{ }^{\circ} \mathrm{C}$, which has been used to substitute naphtha in the petrochemical industry for producing a wide range of chemical products. ${ }^{19}$

Finally, a petroleum condensate was analyzed, the copper content of which had been determined previously in a different laboratory, using direct GFAAS. The value found there was $12.0 \pm 1.7 \mu \mathrm{g}^{-1}$, which is within the range of $2-20 \mu \mathrm{g} 1^{-1}$ of $\mathrm{Cu}$ normally found in this type of sample. Using the proposed procedure values of $13.2 \pm 0.4 \mu \mathrm{g} \mathrm{l}^{-1}$ and $13.8 \pm 0.6 \mu \mathrm{g} \mathrm{l}^{-1}$ were obtained using the standard calibration and analyte addition techniques, respectively. Spiking the petroleum condensate with $15.0 \mu \mathrm{g}^{-1} \mathrm{Cu}$ resulted in a value of $28.9 \mu \mathrm{g} \mathrm{1^{-1 }}$.

\section{Acknowledgements}

The authors are grateful to Fundação de Amparo a Pesquisa do Estado da Bahia (FAPESB), Conselho Nacional de Desenvolvimento Científico e Tecnológico (CNPq) and Coordenação de Aperfeiçoamento de Pessoal de Nível Superior (CAPES) for providing grants and fellowships and for financial support.

\section{References}

1 E. Martinez, R. Cela, A. M. Carro, J. C. Cobas and B. Garcia, J. Anal. At. Spectrom., 2002, 17, 1373.

2 M. C. Yebra and A. Moreno-Cid, J. Anal. At. Spectrom., 2002, 17, 1425 .

3 A. Lopez-Molinero, R. Gimenez, P. Otal, A. Callizo, P. Charmorro and J. R. Castillo, J. Anal. At. Spectrom., 2002, 17, 352.

4 S. L. C. Ferreira, W. N. L. Santos, C. M. Quintella, J. M. BosqueSendra and B. B. Neto, Talanta, 2004, 63, 1061.

5 M. Grotti, E. Magi and R. Leardi, J. Anal. At. Spectrom., 2003, 18, 274.

6 W. N. L. Santos, Aplicação de Matriz de Doehlert na otimização de sistemas de pré-concentração em linha para determinação de zinco e chumbo em águas naturais e efluentes de refinaria de petróleo, $\mathrm{PhD}$ Thesis, Universidade Federal da Bahia, Brasil, 2004.

7 D. L. Massart, B. G. M. Vandeginste, L. M. C. Buydens, S. de Jong, P. J. Lewi and J. Smeyers-Verbeke, Handbook of Chemometrics and Qualimetrics, Part A, Elsevier, Amsterdam, 2003.

8 E. R. Pereira-Filho, R. J. Poppi and M. A. Z. Arruda, Quim. Nova, 2002, 25, 246.

9 I. Koch, C. F. Harrington, K. J. Reimer and W. R. Cullen, Talanta, 1997, 44, 1241.

10 M. V. Rebouças, S. L. C. Ferreira and B. B. Neto, J. Anal. At. Spectrom., 2003, 18, 1267.

11 J. A. A. Amaro and S. L. C. Ferreira, J. Anal. At. Spectrom., 2004, 19, 246.

12 P. Grinberg and de R. C. Campos, Spectrochim. Acta, Part B, 2001, 56, 1831.

13 E. A. Hernandez-Caraballo, M. Burguera and J. L. Burguera, Talanta, 2004, 63, 419.

14 C. Tagoe and W. Ramharry, Hydrocarbon Process., 1993, 117.

15 R. Q. Aucélio, A. Doyle, B. S. Pizzorno, M. L. B. Tristão and R. C. Campos, Microchem. J., 2004, 78, 21.

16 Statistica for Windows, StatSoft, Inc., 2300 East 14th Street, Tulsa, OK 741014, USA, 1999.

17 L. C. Rodríguez, R. B. García, A. M. G. Campaña and J. M. Bosque-Sendra, Chemometr. Intell. Lab. Syst., 1998, 41, 57.

18 W. N. L. dos Santos, C. M. N. Santos, J. L. O. Costa, H. M. A. Carvalho and S. L. C. Ferreira, Microchem. J., 2004, 77, 123.

19 M. V. Rebouças, Determinação de arsênio em nafta e condensado de petróleo por espectrometria de absorção atômica com atomização eletrotérmica utilizando lantânio como modificador, $\mathrm{PhD}$ Thesis, Universidade Federal da Bahia, Brasil, 2004. 